\title{
Kekuasaan Kiai dalam Politik: Modal Fuad Amin sebagai Bupati Terpilih di Kabupaten Bangkalan
}

\author{
Wiwid Adiyanto $^{1}$ dan Rarashanti Wulandhari ${ }^{2 *}$ \\ ${ }^{1}$ Universitas Amikom Yogyakarta dan ${ }^{2}$ Universitas Diponegoro \\ Email:wiwidadiyanto@amikom.ac.id'; rarashantiwulan@gmail.com²* \\ *corresponding author
}

\section{Keywords:}

Power. Kiai, Politic, Cultural Capital

\section{Kata Kunci:}

Kekuasaan, Kiai, Politik, Modal Budaya

\begin{abstract}
The title of kyai in the government became a special polemic in Bangkalan Madura. The purpose of this study is to design a Fuad Amin capital policy to obtain the position of regent in Bangkalan. The method in this research uses a case study using descriptive qualitative. The theoretical basis of this study uses the concept of capital in the theory of Pierre Bourdieu's Habitus as research. This research attempts to describe the successful transition of Fuad Amin to become a regent related to the concept of capital that has not been approved from previous research. The results showed that the symbolic capital owned by Fuad Amin with his title of kiai was an entry point for the Bangkalan community's trust to faithfully entrust Bangkalan to Fuad Amin. Plus the social stratification of Fuad Amin is a descendant of the great scholars of Bangkalan. The kiai is a much-needed figure when running for regency. The economic, cultural, social and symbolic capital of Fuad Amin is interrelated and can support and strengthen one another. Symbol developed for Fuad Amin who can benefit from politics. The novelty of this study is the finding of symbolic conflict as a result of the replacement of Fuad Amin's capital.
\end{abstract}

\begin{abstract}
ABSTRAK
Gelar kyai dalam pemerintahan menjadi polemik tersendiri di Bangkalan Madura. Tujuan dari penelitian ini mendeskripsikan mekanisme modal Fuad Amin untuk mendapatkan posisi bupati di Bangkalan. Metode dalam penelitian ini menggunakan studi kasus dengan pendekatan deskriptif kualitatif. Landasan teori dari penelitian ini menempatkan konsep kapital dalam teori Habitus Pierre Bourdieu sebagai lensa penelitian. Penelitian ini berusaha mendeskripsikan mekanisme keberhasilan Fuad Amin menjadi bupati terkait konsep modal yang belum diteliti secara mendalam dari penelitian sebelumnya. Hasil dari penelitian ini menunjukan bahwa modal simbolik yang dimiliki Fuad Amin dengan gelarnya kiai merupakan entry point kepercayaan masyarakat Bangkalan untuk setia mempercayakan Bangkalan kepada Fuad Amin. Ditambah lagi secara stratifikasi sosial Fuad Amin merupakan keturunan ulama besar dari Bangkalan. Kiai merupakan sosok yang sangat diperlukan saat mencalonkan diri menjadi bupati. Modal ekonomi, budaya, sosial, dan simbolik yang dimiliki Fuad Amin saling berhubungan dan mengalami pertukaran serta penguatan satu sama lain. Hal itu membangun kekuasaan simbolik untuk Fuad Amin yang bisa menguntungkan khususnya secara politik. Kebaruan dari penelitian ini adalah temuan kekerasan simbolik sebagai dampak dari mekanisme kapital Fuad Amin.
\end{abstract}

Copyright (C) 2020 Channel Jurnal Komunikasi. All right reserved. 


\section{PENDAHULUAN}

Fenomena Kiai saat ini disadari telah memberi kekuatan dalam menjalankan politik dalam dunia politik Indonesia. Banyak cara yang digunakan untuk mendukung partai politik untuk mendapatkan kekuasaan. Hal inilah yang dilakukan oleh mantan bupati kabupaten Bangkalan yang sudah menguasai Bangkalan selama dua periode kemudian diteruskan kepada anak laki-lakinya dikenal dengan nama Ra Momon. Awalnya Fuad Amin Imron akan mendelegasikan istri mudanya sebagai calon bupati Bangkalan, tapi diurungkan karena dikhawatirkan para masyarakat akan mundur untuk mendukung. Menurut Supriyadi (2015:74) pilkada merupakan salah satu wujud sistem penyelenggaraan dari negara yang demokratis.

Fuad Amin divonis sebagai tersangka korupsi Anggaran Pendapatan Belanja Daerah (APBD) sebesar 414 miliar di tengah karirnya. Semasa menjadi Bupati, Fuad Amin juga melakukan kecurangan dengan jual beli jabatan untuk Surat Kuasa Pegawai Negeri Sipil mulai dari 15 juta sampai 50 juta. Selain itu Fuad Amin juga meminta upeti kepada pengusaha migas yang ada di Bangkalan sebesar 200 juta hingga 1 miliar per-bulan (Saputra, 2018).

Fuad Amin juga tidak memberikan pengaruh yang signifikan pada wilayah yang diwakilinya. Secara umum, seluruh daerah di Madura termasuk kabupaten Bangkalan merupakan daerah termiskin di Jawa Timur pada periode 20132015 dengan rata-rata 21,86\%. Itu melebihi angka kemiskinan nasional pada saat itu yang berada pada angka 11,19\%. Madura juga menyandang pendapatan perkapita yang rendah di masyarakatnya yaitu 9 juta sampai 15 juta per tahun. Angka Partisipasi Sekolah untuk jenjang SMA juga masih dirasa rendah yaitu diangka 58,7\% dimana rata-rata angka di Jawa Timur adalah 70,4\% (Okezone.com, 2017).

Kabupaten Bangkalan tidak menunjukan kemajuan yang signifikan selama masa pemerintahan Fuad Amin. Suramadu yang diharapkan bisa mendongkrak kemajuan perekonomian Madura terutama Bangkalan sebagai pintu masuk Madura, ternyata berjalan tidak sesuai ekspektasi. APBD Bangkalan masih bergantung pada subsidi negara. Pendapatan Asli Daerah berada pada angka 20\% yaitu sekitar 200 miliar dari lebih dari 2 triliun APBD kabupaten Bangkalan. Itu menunjukan sekitar 80\% APBD bergantung pada subsidi negara (Sahuri, 2019).

Di sejarah Bangkalan belum ada seorang bupati perempuan, dari awal kepemimpinan bupati Bangkalan dipimpin oleh laki-laki. Sebagian besar yang menjabat bupati berketurunan bangsawan dan Kiai. Masyarakat Madura sangat lekat dengan tokoh Kiai, menurut Wijaya peranan Kiai selain sebagai pembina umat, juga mengajarkan ilmu agama kepada santri (2006:49) terdapat banyak pondok pesantren yang ada di Madura, penduduk Madura banyak yang menganut agama islam, dalam kehidupan sehari-hari sangat menjunjung tinggi nilai agama. Kiai tidak hanya digunakan sebagai orang yang mengerti agama, tapi juga digunakan sebagai pendukung politik merebut kekuasaan untuk menduduki jabatan eksekutif dan legislatif.

Fuad Amin berasal dari golongan kyai, priyayi, dan blater yang secara sosial tumbuh dalam tradisi blater (Raditya, 2019). Di kabupaten Bangkalan Fuad Amin sangat dikenal karena keturunan (cicit) dari pendiri pondok pesantren terkenal di Madura yaitu kyai Syaichona Cholil. Fuad Amin juga masih memiliki keturunan bangsawan di Bangkalan, oleh karena itu beliau dihormati oleh masyarakat. Menurut Barton (dalam Abdussalam, 2015:4). Masyarakat percaya jika anak-anak mereka mengamalkan agama islam di pondok akan mendapatkan berkah dari kyai. Kiai Cholil merupakan guru Kiai Hasyim Asy'ari ulama pendiri NU di Indonesia. Dalam kekuasaan Fuad Amin kebebasan menyampaikan pesan tidak bisa dilakukan, seperti halnya pada kepemimpinan Soeharto sebagai presiden di Indonesia, hal ini disebabkan karena Madura sangat terkenal dengan blater (pelaku tindak kriminal). Di Madura blater ini memiliki kendali di desa-desa, terlebih lagi Fuad Amin telah mengenal dunia blater.

Penelitian sebelumnya, Ja'far (2014:192) menyatakan bahwa dalam perspektif kultur Madura munculnya "BupatiKiai” seperti "menyimpang" dari filosofi orang Madura. Dalam bidang kehidupan yang menjadi ranah otoritas Kiai (guru) dan ranah kekuasaan bupati (rato). Tentu saja rangkap posisi tidak akan dimaknai sebagai "penyimpangan" yang akhirnya akan merugikan orang Madura, jika "Bupati-Kyai" yang menjabat bisa menunjukkan kinerja ketika menjalankan jabatannya. Bila kyai yang menjadi bupati tidak bisa menjalankan tanggung jawabnya maka bisa saja masyarakat menjadi tidak percaya dengan kinerjanya, hal ini akan memberikan efek buruk terhadap masyarakat.

Menurut Satriawan (2016:111) negara demokratis adalah negara yang melaksanakan suksesi kepemimpinan secara reguler lima tahun sekali. Pilkada langsung ditegaskan dalam UU No. 32 Th. 2004 tentang pemerintah daerah sebagai hasil revisi UU No. 22 Th. 1999 (Warsito. 2005:914). Dengan gelar Kiai yang dimiliki oleh Fuad Amin dapat memberi pengaruh masyarakat Bangkalan pada saat pemilihan bupati pada tahun 2003-2008 menang mutlak diusung oleh PKB, sebelum menyelesaikan tugasnya menjadi bupati pada tahun 2008 Fuad Amin masih ingin menjabat di dunia politik dengan mencalonkan lagi menjadi bupati dan terpilih untuk kedua kalinya untuk periode tahun 2008-2013.

Setelah menjabat bupati selama dua periode Fuad Amin tidak bisa mencalonkan kembali, untuk tetap mempertahankan kekuasaan, anak laki-lakinya yaitu Ra Momon yang sudah mendapatkan gelar Kiai karena keturunan kyai Cholil mencalonkan diri sebagai calon bupati bersama ra imam (sepupu Fuad Amin) berhasil menjabat untuk tahun 2013-2018 memperoleh suara sebanyak 90\% (Ruji, 2016:57). Kemenangan Ra Momon semakin memperkuat dinasti kepemimpinan Fuad Amin yang turun kepada anaknya. Terlebih lagi pada tahun 2013-2018 ketika anaknya menjadi 
bupati Bangkalan Fuad Amin terpilih menjadi ketua DPRD Bangkalan. Di Dalam keterpilihan Ra Momon sebagai bupati masih ada bayang-bayang dari Fuad Amin karena lebih berpengalaman dalam dunia politik.

Fenomena pemerintah dan kiai menjadi hal yang menarik untuk dilihat dari segi komunikasi. Interaksi masyarakat pada pemerintah yang menyandang gelar kiai berpotensi menimbulkan permasalahan sosial. Interaksi tersebut juga tidak lepas dari bagaimana sosio kultural masyarakat Bangkalan. Penelitian sebelumnya tidak membahas secara rinci bagaimana mekanisme kapital Fuad Amin sehingga menang dalam pemilihan bupati Bangkalan. Kebaruan dari penelitian ini adalah fokus pada mekanisme kapital yang dimiliki Fuad Amin sehingga dirinya bisa terpilih kembali menjadi bupati Bangkalan Madura. Tujuan penelitian ini adalah mendeskripsikan mekanisme kapital dari Fuad Amin yang membuat dirinya terpilih menjadi Bupati Bangkalan.

\section{TINJAUAN PUSTAKA}

Kegiatan menyangkut masalah memperebutkan dan mempertahankan kekuasaan dan biasanya dianggap bahwa perjuangan. Penelitian sebelumnya yang dilakukan Mu'azaroh (2017) membahas tentang cultural capital K.H. Maimun Zubair dalam dinamika politik. Hasilnya adalah K.H Maimun melakukan penyeimbangan untuk pengaplikasian agama Islam dengan kehidupan politik. Modal simbolik kiai berhasil menempatkan K.H Maimun mendapatkan peran Ketua Majelis Syariah melalui Partai Persatuan Pembangunan (PPP) dimaknai sebagai modal untuk penyelenggaraan pemerintahan dengan nilai-nilai Islam. Selanjutnya penelitian dari Fauzi (2018) membahas tentang habitualisasi nilainilai kepemimpinan transformatif kyai Hasan Mutawakkil 'Alallah di Probolinggo. kiai Hasan Mutawakkil 'Alallah dalam kepemimpinannya dipengaruhi dan dibangun oleh geneologi keilmuan dari kiai sebelumnya yaitu kyai Moh Hasan dan kiai Hasan Saifouridzall. Dan hasilnya kebiasaan dari kiai sebelumnya dijadikan role model untuk kepemimpinannya dan penerapan ilmu secara turun temurun menjadi suatu kebiasaan yang akhirnya menyangkut hal kepemimpinannya. Hasil dari penelitiannya menyimpulkan, habitualisasi nilai-nilai agama dari kyai sebelumnya dinilai efektif untuk kepemimpinan dalam sistem organisasi yang tidak lepas dari nilai-nilai internal pesantren.

Penelitian tentang politik juga dilakukan oleh Pramudhita, Anang, dan Antoni (2018) terkait hegemoni yang merambah pada industri radio. Pramudhita menggunakan pendekatan ekonomi politik dalam penelitiannya terkait dengan tangga lagu dengan format Contemporary Hits Radio (CHR) di radio-radio yang ada di Indonesia, Data riset Nielsen terkait rating radio di Indonesia, dan dokumen market share industri rekaman dalam rentan waktu 2005 sampai 2011. Hasil dari penelitian tersebut menunjukan bahwa industri musik Indonesia tidak terlepas dari hegemoni ataupun dampak kekuasaan dari kapitalisme global walaupun seharusnya seni yang sesungguhnya adalah bebas nilai. Penelitian terkini terkait dengan politik dan kekuasaan juga dilakukan oleh Marhaeni dan Mulyadi (2019) yang meneliti politik kapitalis dalam tayangan iklan di Internet. Metode yang digunakan adalah semiotika yang menghasilkan penjelasan secara deskriptif praktek dominasi politik tersebut dalam media. Hasilnya adalah bentuk kekuasaan yang tayang pada iklan di media online disimbolkan dengan gambaran kemakmuran, kebahagiaan, kerukunan, kasih sayang, dan kecukupan. Hal itu membuat konsep keidealan menjadi natural dan merupakan goal dari anak maupun orang tua yang tentunya yang didukung hanya oleh produk yang diiklankan.

Dari beberapa penelitian sebelumnya tentang kekuasaan tokoh maupun kapitalis, artikel ini berusaha kembali dalam sudut pandang kekuasaan pemerintahan dan mengisi hal yang belum dibahas secara mendalam yaitu tentang modal yang dimiliki Fuad Amin sehingga terpilih menjadi bupati Bangkalan. Bourdieu (dalam Dwizatmiko, 2010:4) mengatakan bahwa kehidupan bernegara (state) kekuasaan itu terkait dengan kenyataan yang ada (visible), misalnya organisasi masyarakat mengikuti norma-norma yang berlaku dangan nyata (visible) pada organisasi itu oleh peraturan lembaga pemerintah/negara. Berdasarkan penelitian yang sudah ada tersebut, penelitian ini berusaha menjawab pertanyaan bagaimana mekanisme modal yang dimiliki Fuad Amin dalam menggapai kepercayaan masyarakat Bangkalan? Pada akhirnya tujuan penelitian ini adalah mendeskripsikan hubungan-hubungan modal yang dimiliki Fuad Amin termasuk mekanisme pembentukan kekuasaannya dan dampaknya bagi masyarakat Bangkalan.

\section{A. Kiai}

Kiai memiliki istilah yang luas. Tokoh agama atau kyai merupakan orang yang disegani, dihormati, dan kadang ditakuti. Rasa segan, hormat, dan takut masyarakat itu tercipta karena Kiai mampu memberikan rasa aman, nyaman, dan damai di daerahnya. Bahkan seringkali mampu memberikan solusi atas persoalan yang dihadapi masyarakat (Yahya, 2014:192). Bermacam-macam pendapat menurut ahli, menurut Hiroko Horikoshi (dalam Susanto, 2007:33) Masyarakat Madura dan Jawa memiliki pandangan jika ulama memiliki posisi lebih rendah dari Kiai.

Saat Indonesia memasuki era Reformasi tatanan relasi Kiai dan masyarakat Madura yang telah lama terjalin itu sedikit mengalami perubahan. Era keterbukaan ini, telah memungkin bagi seorang Kiai yang sebelumnya hanya berfungsi sebagai patron politik-untuk terjun langsung dalam dunia politik, dengan menduduki jabatan-jabatan, baik sebagai anggota legislatif maupun duduk sebagai pimpinan eksekutif (Ja'far, 2014:181). Di Jawa Timur, elite politik yang berbasis agama dan pesantren dikenal dengan sebutan "santri", "kiai", atau keluarga kiai yang dikenal dengan sebutan 
"Gus" (istilah yang melekat pada kiai Jawa), atau "Lora" (istilah yang melekat pada kiai Madura), atau juga "Bhindhârâh" (istilah yang melekat pada kiai Pendalungan/Jawa Timur bagian Timur dan Selatan). Ketiganya adalah sama, yakni anak dan keturunan kiai, terutama, yang memiliki pesantren. Tetapi, sebutan tersebut sangat populer bagi anak dan keturunan kiai yang memiliki pesantren (Chalik, $2015: 371)$.

Gelar kiai didapat dengan cara yang berbeda-beda. Kiai yang ada dalam khazanah budaya Indonesia misalnya adalah Kiai keturunan, yakni orang-orang yang menjadi Kyai dikarenakan merupakan keturunan dari kyai yang memiliki Pesantren. Jenis yang lain adalah kyai yang mengajarkan mengaji. Pada umumnya, Kiai jenis ini diangkat disebut Kiai oleh masyarakat, karena keilmuan yang dimilikinya. Selain varian-varian di atas, terdapat pula jenis Kiai yang berceramah. Pada dasarnya, Kiai model ini bisa berasal dari keturunan Kiai atau bisa juga berasal dari kalangan biasa. Kiai terhadap seseorang yang biasa bertugas sebagai pemimpin ritual-ritual, semisal ritual-ritual kematian, kelahiran bayi maupun ritual-ritual yang lain, termasuk di dalamnya ritual-ritual adat yang tidak memiliki keterkaitan dengan nilainilai teologis (Ja'far, 2014:186). Terkait dengan relasi masyarakat-Kiai ini bahwa apapun akan dipertaruhkan oleh warga Madura, demi membela kehormatan dan eksistensi seorang Kiai. Hal tersebut dilakukan mengingat bahwa sosok Kiai bagi warga Madura adalah segala-galanya, yang keberadaanya termasuk keturunannya harus dijaga dan dihormati tanpa reserve (Ja'far, 2014:181).

\section{B. Politik}

Menurut PJ. Bouman partai politik adalah suatu kelompok yang terorganisir yang anggota-anggotanya mempunyai orientasi nilai-nilai dan cita-cita yang sama. Tujuan kelompok ini adalah untuk memperoleh kekuasaan politik dan merebut kedudukan politik dengan cara konstitusional, serta menumbuhkan partisipasi masyarakat (Yahya, 2014:190). Sedangkan menurut Ramlan Surbakti partai politik sebagai kelompok anggota yang terorganisasi secara rapi dan stabil yang dipersatukan dan dimotivasi dengan ideologi tertentu, dan yang berusaha mencari dan mempertahankan kekuasaan dalam pemerintahan melalui pemilihan umum dan cara-cara lain yang sah guna melaksanakan alternatif kebijakan umum yang mereka susun, sebagai hasil dari pemaduan berbagai kepentingan yang hidup dalam masyarakat (Yahya, 2014:190). Berlandas dari partai islam dan memiliki tujuan yang sama ini memunculkan ide untuk menjalankan partai politik islam dengan bergabung dan membuat partai, islam sendiri sudah memiliki wadah sendiri dalam pondok pesantren yang diasuh oleh Kiai yang mengerti tentang agama.

Masyarakat Madura sangat berpegang teguh dengan agama, tidak diragukan lagi bahwa di Madura terdapat banyak pesantren yang menghasilkan penghafal Al-Qur'an. Para santri pada siang hari belajar mendalami ilmu ke sekolah agama yang diadakan oleh pondok pesantren di desa dilanjutkan untuk sore hari mereka belajar mengaji pada ustadz dan kyai. Dukungan dari Kiai sangat mudah didapatkan oleh Fuad Amin yang berlatar belakang keturunan Kiai terkenal. Sejak pemilu pertama dilangsungkan di era reformasi koalisi partai politik sebagai bentuk power sharing sudah terbentuk dengan segala dinamika kepentingannya. Koalisi plus ini sejatinya menjadi kekuatan di parlemen untuk mendorong terciptanya pemerintahan yang stabil (Ihsan, 2011:34).

Karir politik Fuad Amin di mulai sejak terpilih menjadi ketua DPC PPP Bangkalan menggantikan posisi ayahnya. Terjun ke politik praktis sesungguhnya bukan pilihannya tapi karena permintaan ayahnya Kiai Amin Imron yang merupakan dedengkot PPP Bangkalan dan anggota DPR RI di era orde baru. Kiai Amin imron disebutnya sebagai guru politiknya yang pertama kali mengenalkan dirinya kepada dunia politik, khususnya politik praktis.

RKH Fuad Amin menjadi Bupati Bangkalan sejak terpilih melalui mekanisme pemilihan suara di DPRD untuk periode 2003-2008 dengan diusung oleh PKB dan berpasangan dengan Muhammad Dong dari PDIP. PKB yang merupakan Fraksi mayoritas di parlemen dengan rincian FKB 25 kursi dan PDIP sebanyak 7 kursi, sementara calon bupati yang lain Ir H Sulaiman dan Sunarto BA diajukan oleh FPAU. Kemenangan RKH Fuad Amin didukung hampir mayoritas anggota parlemen dengan jumlah total 42 suara dengan demikian mendapat tambahan 5 suara dari fraksi TNI/Polri dan FPAU sebanyak 5 suara (Ruji, 2016).

Literatur yang sudah ada telah menyajikan deskripsi dari masyarakat Bangkalan Madura dan perjalanan karir Fuad Amin dalam pemerintahan. Penelitian ini juga berangkat dari penelitian Ja'far (2014) yang menyatakan fenomena kyai menjadi bupati telah menyimpang dari filosofi masyarakat Madura. Selain itu Wiyata (2006) dalam bukunya mendeskripsikan konflik kekerasan dan harga diri orang Madura yang membahas juga tentang pemerintahan di Madura. Dari beberapa literatur tersebut, penelitian ini berusaha untuk mengisi blind spot yang masih belum dikaji secara mendalam, yaitu mekanisme keberhasilan Fuad Amin menjadi bupati Bangkalan yang fokus terkait modal yang dimilikinya. Hal ini juga untuk mengetahui dampak yang ditimbulkan dari mekanisme pengelolaan modal Fuad Amin pada masyarakat Bangkalan.

\section{METODE PENELITIAN}

Penelitian kekuasaan Kiai dalam politik bupati Fuad Amin kabupaten Bangkalan, menggunakan pendekatan penelitian kualitatif analisis deskriptif. Menurut Neuman (2013:44) bertujuan untuk memberikan gambaran dengan 
menggunakan kata-kata dan angka serta menyajikan profil persoalan, mendokumentasikan proses sebab akibat berdasarkan fakta.

Penelitian ini merupakan penelitian studi kasus terhadap keterpilihan Fuad Amin sebagai bupati Bangkalan selama 2 periode walaupun dengan serangkaian kasus yang terkait dengannya. Studi kasus mengacu pada keunikan suatu peristiwa yang terkait dengan latar belakang sejarah dari peristiwa tersebut (Stake dalam Pramudyanto, 2013:70). Data utama dalam penelitian ini didapat dari wawancara kepada 4 penduduk Bangkalan yang memilih Fuad Amin untuk menjadi bupati. Data sekunder yang digunakan didapat dari buku, jurnal, dan berita online yang berkaitan dengan Kiai atau politik Fuad Amin. Menurut Bourdieu (dalam Dwizatmiko, 2010:66), bahasa merupakan bagian dari fenomena sosial, termasuk praktik bahasa serta kuasa simbolik, terdapat tiga konsep: habitus, arena (field) dan modal (capital). Habitus merupakan pembiasaan berulang-ulang yang dilakukan dengan sadar atau tidak sadar yang berasal dari ciptaan sejarah dan budaya. The field (arena sosial) merupakan ruang khusus yang memiliki aturan main sendiri-sendiri di dalam masyarakat, bila orang ingin berhasil mereka harus memiliki habitus dan kapital yang benar. Kapital merupakan modal yang memungkinkan kita mendapatkan kesempatan di dalam interaksi sosial.

Pembagian kultural masyarakat dengan berbagai cara, dalam teorinya Bourdieu menyatakan bahwa tindakan sosial merupakan struktur tindakan itu sendiri dan keduanya dapat saling dipertukarkan. Negosiasi di dalam budaya berasal dari kesadaran habitus, dan pada tingkatan individu, habitus juga berarti sistem perilaku dan disposisi yang relatif permanen dan berpindah dari satu objek ke objek lainnya secara simultan dalam mengintegrasikan antara seluruh pengalaman sebelumnya. (Adib, 2012:95)

Bourdieu tetap menganggap penting modal ekonomi, yang di antaranya adalah alat-alat produksi (mesin, tanah, tenaga kerja), materi (pendapatan, benda-benda), dan uang. Modal ekonomi merupakan modal yang secara langsung bisa ditukar, dipatenkan sebagai hak milik individu. Modal ekonomi merupakan jenis modal yang relatif paling independen dan dan fleksibel karena modal ekonomi secara mudah bisa digunakan atau ditransformasi ke dalam ranah-ranah lain serta fleksibel untuk diberikan atau diwariskan pada orang lain. (Krisdinanto, 2014:203)

Namun selain modal ekonomi, Bourdieu (dalam Krisdinanto, 2014: 203) juga menyebut modal simbolik, modal kultural, dan modal sosial:

"Kekuatan-kekuatan sosial yang dasar adalah, ketika menurut penyelidikan empiris, pertama modal ekonomi, dalam berbagai jenisnya; kedua modal kultural, modal informasi, dalam berbagai jenisnya; dan yang ketiga adalah ketika dua jenis modal saling berhubungan, modal sosial, yang terdiri dari sumber daya yang memiliki koneksi dan keanggotaan grup, dan modal simbolis, yang merupakan jenis modal lain yang sering dirasakan dan diakui dengan sah (Calhoun dalam Calhoun: 1993; p. 170)."

Definisi modal menurut Bourdieu menyangkut hal-hal material yang memiliki nilai simbolik yang tidak tersentuh namun memiliki signifikansi secara kultural seperti prestise, status, dan otoritas yang merupakan modal simbolik, serta modal simbolik. Modal budaya dapat mencangkup luasnya properti seperti seni dan bentuk bahasa. Bourdieu mengungkapkan bahwa modal mempunyai peran sebagai sebuah relasi sosial yang terdapat dalam suatu sistem pertukaran, baik materil maupun simbol (Bourdieu dalam Harker, 2009:16). Agar dapat dipandang sebagai seseorang atau kelas yang berstatus mempunyai prestise, berarti ia harus diterima sebagai sesuatu yang dilegitimasi. Posisi tersebut membawa kekuasaan untuk mewakili pendapat umum dan juga kekuatan untuk menciptakan versi dunia yang resmi. Kekuasaan untuk mempresentasikan tersebut berawal dari modal simbolik (Bourdieu dalam Harker, 2009:17).

\section{HASIL DAN PEMBAHASAN}

\section{A. Modal Ekonomi Fuad Amin}

Modal ekonomi, yang mencakup alat-alat produksi (mesin, tanah, buruh), materi (pendapatan dan benda-benda) dan uang yang dengan mudah digunakan untuk segala tujuan serta diwariskan dari satu generasi ke generasi berikutnya (Bourdieu dalam Hermansyah, 2015:34). Perekonomian masyarakat Bangkalan didominasi oleh mata pencaharian sektor agraris, pedagang, dan buruh terutama sebagai Tenaga Kerja Indonesia (TKI) di luar negeri. Sektor agraris juga tidak berjalan dengan baik. Salah satu narasumber yaitu Saiful (57 tahun) yang bekerja sebagai petani menyatakan bahwa kendala yang dihadapi adalah kekurangan air untuk menunjang pertaniannya, sehingga penghasilan sangat bertumpu pada musim penghujan. Sedangkan pada musim kemarau, narasumber mengalami keterbatasan terkait jenis tanaman yang bisa ditanam. Biasanya mengandalkan penanaman singkong. Namun bila tidak memungkinkan untuk menanam apapun, persawahan hanya dijadikan arena gembala ternak.

Sosok Fuad Amin yang dipandang mempunyai perekonomian yang mumpuni, mampu mempengaruhi narasumber untuk berharap ada kemajuan dan bantuan dari pemerintahannya. Ditambah lagi, pada saat kampanye, Fuad Amin secara bergantian menyelenggarakan pengajian dalam rangka memanjatkan doa untuk kesejahteraan rakyatnya di beberapa desa di Bangkalan. Narasumber juga mengetahui bahwa Fuad Amin tidak hanya bisa menyelenggarakan pengajian di lingkungannya, tapi Fuad Amin juga mampu mengadakan pengajian di pondok pesantren yang ada di sejumlah daerah Bangkalan. Selain itu, Fuad Amin juga pernah mengadakan program pelatihan menjahit bagi ibu-ibu di lingkungannya saat 
dia menjabat di periode pertamanya. Hal tersebut disambut baik karena dengan adanya pelatihan tersebut memungkinkan terbukanya pendapatan baru selain bertani, yaitu menjahit.

"Fuad Amin itu doanya kuat. Dimana-mana diadakan pengajian untuk mendoakan kita semakin sejahtera pada khususnya dan Bangkalan menjadi lebih maju pada umumnya. Mengadakan pengajian itu kan sedekah dek, dia dapat doa, kami juga dapat pahala. Saat seperti itu yang kami tunggu, bertemu langsung dan berdoa bersama dari orang yang kami dukung. Disini orang-orang Fuad Amin banyak dek. Untuk mengadakan acara seperti itu orang-orangnya turun tangan langsung. Ya, ikut bantu”.

Kutipan tersebut menunjukan bahwa, Fuad Amin mempunyai kemampuan finansial yang cukup untuk membiayai pengajian dan pelatihan yang merupakan acara harapan dari masyarakatnya. Fuad Amin bisa menjangkau lebih banyak masyarakat dengan perekonomian yang melekat pada dirinya. Hal tersebut didukung dengan alat transportasi dan sumber daya manusia yang dia miliki.

Narasumber Mukarom (38 tahun) dan Kholis (45 tahun) yang juga bekerja sebagai petani menyatakan hal serupa dengan narasumber pertama, bahwa mereka menaruh harapan besar pada Fuad Amin. Kekayaan yang dimiliki Fuad Amin menjadi modal tersendiri dalam pembentukan salah satu identitas Fuad Amin sebagai orang yang kaya yang bisa membangun Bangkalan. Narasumber beranggapan dengan kekayaannya tersebut Fuad Amin bisa berbuat sesuatu untuk lebih mensejahterakan rakyat pada wilayahnya. Meskipun narasumber mengaku tidak mendapatkan uang baik secara langsung maupun tidak dari Fuad Amin selama masa kampanyenya, kedua narasumber itu beranggapan bahwa dengan kekayaan yang dimiliki, Fuad Amin lebih pantas menduduki jabatan sebagai bupati dibanding pesaing lainnya. Narasumber juga mengaku tidak begitu paham tentang kelebihan kandidat lainnya.

Lain hal nya dengan narasumber Samsul yang bekerja sebagai pegawai honorer di kantor bupati Bangkalan. Superioritas Fuad Amin di kantornya, membuat narasumber seakan tidak mempunyai pilihan lain selain memilih Fuad Amin dalam melanjutkan jabatannya menjadi bupati. Hal tersebut dituturkan oleh laki-laki 29 tahun itu karena pengabdiannya kepada Fuad Amin yang memberikan kesempatan kepadanya untuk bekerja di kantor pemerintahan tersebut. Samsul juga mengaku terbawa oleh lingkungan kerjanya, bahwa di lingkungan kerjanya hampir semuanya adalah pendukung Fuad Amin. Dia tidak berani untuk tidak mendukung atasannya tersebut. Hal tersebut dikarenakan pekerjaannya bergantung pada Fuad Amin sebagai pihak pemegang wewenang. Selain itu narasumber merasa berada dalam ancaman walaupun tidak ada yang mengancam bila dia berpaling dukungan dari Fuad Amin. Hal tersebut dituturkan karena kemungkinan berada di lingkungan orang-orang yang mendukung Fuad Amin. Narasumber yang berpendidikan SMA ini juga menuturkan bahwa untuk mencari pekerjaan di Bangkalan sangat sulit. Walaupun penghasilan perbulan diakuinya kecil, namun bekerja di kantor pemerintahan merupakan kebanggaan tersendiri bagi dirinya dan keluarganya dengan harapan ada pengangkatan menjadi Pegawai Negeri Sipil. Selain itu, narasumber ini juga mengaku pernah mendapat kesempatan untuk mengikuti pelatihan komputer setelah bekerja di kantor pemerintahan bupati Bangkalan.

Narasumber keempat ini juga menyatakan kebanggaan atas dirinya dibanding dengan beberapa anggota keluarga besarnya. Keluarga besarnya yang dulu di Bangkalan, kini banyak yang bekerja ke luar negeri seperti Malaysia dan Arab sebagai asisten rumah tangga, dengan visa umroh mereka memberanikan diri mencari pekerjaan melalui saudara-saudara mereka yang sudah ada di arab. Mereka berani menanggung resiko penyalahgunaan visa umroh, bila tertangkap oleh polisi Arab mereka akan ditahan beberapa minggu di penampungan untuk selanjutnya di pulangkan ke negara masing-masing. Hal ini mereka lakukan karena menyadari bahwa di Bangkalan belum ada pekerjaan yang mendukung kemampuan mereka, dan juga gaji yang mereka hasilkan lebih banyak bila di rupiahkan. Mereka akan membangun rumah, membeli sawah untuk menampakkan keberhasilan ketika kerja di luar negeri.

Fuad Amin dalam hal ini mempunyai tempat yang dikuasai yaitu kantor pemerintahan bupati Bangkalan yang dimana narasumber merupakan sumber daya manusia yang dimiliki olehnya. Hal tersebut karena kantor tersebut merupakan salah satu area pendapatan Fuad Amin sebagai pimpinan yang tertinggi. Dengan kata lain Narasumber merupakan buruh yang bekerja untuk Fuad Amin. Dengan begitu Fuad Amin mempunyai kuasa lebih untuk mengatur pola pikir dan pendapatan suara dari sumber daya manusia yang dia miliki. Fuad Amin tanpa mengancam secara langsung bisa membuat seorang merasa terancam karena struktur yang ada di kantor tersebut. Selain itu, Fuad Amin punya orangorang yang dipekerjakannya untuk mendukung dirinya sekaligus saling mengawasi satu dengan lainnya agar tetap dalam suara Fuad Amin. Keempat narasumber meyakini Fuad Amin tidak akan melakukan korupsi karena sudah mempunyai banyak harta keturunan. Karena tidak bisa dipungkiri bahwa pilkada menghabiskan banyak biaya secara pribadi. Yang paling dibutuhkan oleh masyarakat Bangkalan adalah percaya dengan pemimpin yang bisa menjalankan tanggung jawab.

\section{B. Modal Budaya Fuad Amin}

Modal budaya, yang mencakup keseluruhan kualifikasi intelektual yang dapat diproduksi melalui pendidikan formal maupun warisan keluarga. Misalnya kemampuan menampilkan diri di depan publik, kepemilikan benda-benda budaya bernilai tinggi, pengetahuan dan keahlian tertentu dari hasil pendidikan, juga sertifikat gelar kesarjanaan (Bourdieu dalam Hermansyah, 2015:34). Modal budaya yang melekat pada diri Fuad Amin adalah gelarnya sebagai kiai 
dan keturunan kiai besar. Budaya yang ada di Bangkalan Madura, memposisikan kiai sebagai golongan yang memiliki stratifikasi sosial tinggi. Hal tersebut membuat Fuad Amin menguasai dan memanfaatkan tradisi-tradisi budaya yang ada di bangkalan. Salah satu cara yang bisa digunakan dengan modal budaya yaitu intelektual dari calon bupati. Pada masa jabatan menjadi bupati sempat tersebar kabar bahwa ijazah pendidikan Fuad Amin di salah satu Universitas di Bangkalan palsu. Namun hal ini tidak mempengaruhi narasumber yang mana adalah masyarakatnya untuk tidak memilih Fuad Amin. 3 dari 4 narasumber dalam penelitian ini tidak terlalu memperdulikan keabsahan dari ijazah Fuad Amin. Mereka tidak berusaha untuk mencari tahu apakah ijazahnya tersebut bisa dipertanggungjawabkan. Salah satu narasumber sempat mencari tahu namun tidak secara mendalam karena kurangnya akses informasi. Fuad Amin tetap dipandang sebagai orang yang berintelektual tinggi. Selain itu keempat narasumber lebih menaruh perhatian pada strata Fuad Amin sebagai kiai sekaligus keturunan dan berada di keluarga besar kyai dari pada bukti otentik akademik dari Fuad Amin.

Modal budaya dalam pemerintahan juga telah Fuad Amin dapatkan dalam kemenangannya di periode pertama. Bergabungnya Fuad Amin dalam Partai Kebangkitan Bangsa (PKB) juga menunjang kepemilikan modal budaya politik Fuad Amin untuk maju dalam pemilihan bupati Bangkalan. Dengan pengalamannya di politik, dia mengerti budaya perpolitikan untuk meraih kekuasaan. Ketiga narasumber menuturkan ilmu agama jauh lebih penting dari pada ilmu akademik dalam perkuliahan atau sekolah. Dengan menyandang status kiai, Fuad Amin dianggap mempunyai kemampuan dalam hal agama yang mumpuni dan tingkatannya jauh lebih tinggi dari masyarakat bangkalan. Tradisi Bangkalan Madura memandang bahwa, orang yang berstatus kiai ataupun yang memiliki kemampuan agam yang tinggi harus dihormati dan pantas menjadi panutan. Dengan adanya keterkaitan figur kiai yang ditinggikan dalam budaya Bangkalan Madura, itu menjadi modal budaya yang telah dikuasai Fuad Amin. Modal budaya yang melekat di diri Fuad Amin tentang kiai itu yang berdampak pada kekuatan Fuad Amin sehingga dipilih kembali dalam periode keduanya.

\section{Modal Sosial Fuad Amin}

Modal sosial, merujuk pada jaringan sosial yang dimiliki pelaku (individu atau kelompok) dalam hubungan dengan pihak lain yang memiliki kuasa (Bourdieu dalam Hermansyah, 2015:34). Narasumber Saiful mempunyai pandangan bahwa, budaya pengagungan figur kiai tersebut harus tetap dilestarikan. Kiai dianggap sebagai figur yang mendatangkan keberkahan dari tuhan. Apalagi bila kiai tersebut adalah kiai besar yang mempunyai banyak pengikut. Hal tersebut juga berlaku pada keturunannya. Fuad Amin merupakan keturunan tokoh ulama besar Syaichona Cholil. Dalam hal ini Fuad Amin juga sudah mendapat modal budaya dari stratifikasi sosial yang ada di Bangkalan Madura.

Ketiga narasumber mengaku bukan saja bangga akan sosok Fuad Amin, namun lebih lanjut ketiga narasumber secara mendasar bangga akan tokoh ulama besar Syaichona Cholil yang berasal dari tanah Madura. Dari penjelasan narasumber tersebut, Bangkalan Madura mempunyai sistem stratifikasi sosial yang tertutup, dimana kasta tertinggi adalah sosok kiai. Semakin besar pengaruh kiai tersebut, maka semakin tinggi stratanya. Begitu juga pada keturunannya, yang menempati jabatan penting hanya berasal dari kalangan kiai atau sesama golongan maupun keluarga.

Saat menjabat sebagai bupati Fuad mencari suara melalui kapital sosial salah satunya dengan berkoalisi dengan partai politik, melalui kekuasaan pesantren yang diasuh meneruskan pesantren milik Syaichona Cholil, selain itu modal kultur oleh Kiai juga dilakukan di langgar-langgar kecil di seluruh pelosok desa Bangkalan. Model rumah masyarakat Madura memiliki bangunan mushola keluarga di setiap masing-masing rumah dengan posisi di depan rumah di sebelah kanan. Dari jaringan keluarga juga masih memiliki keturunan bangsawan, ayahnya sendiri merupakan seorang politikus dan seorang Kiai. Hal tersebut membuat modal sosial Fuad Amin baik di lingkup politik, pemerintahan, maupun masyarakat menjadi kuat.

Dari segi status Fuad Amin sendiri merupakan cucu dari ulama besar di Madura. dinasti politik trah kyai sangat terasa pada periode pemilu. Contohnya Fuad Amin tercatat sebagai pengurus PKB (menjabat sebagai wakil ketua DPW PKB jatim), pada pemilu 1999 dan 2004, PKB mendapat 24 kursi. (Ruji, 2016:56). Pada tahun 2008 Fuad Amin mencalonkan kembali menjadi bupati dan terpilih kembali menjadi bupati. Begitu besar pengaruh modal sosial yang dimiliki oleh Fuad Amin sehingga dia berencana untuk melanjutkan mencalonkan anaknya Ra Momon menjadi bupati dengan mendapatkan hasil suara sebanyak $90 \%$.

Politik di Madura sangat dipengaruhi oleh terkenalnya Kiai sebagai ulama yang dihargai dari jaman dahulu, terlebih lagi masyarakat yang ada di desa-desa terpencil, dalam wujud menghargai Kiai. Hal ini seperti pendapat Bourdieu Modal simbolik mengacu pada derajat akumulasi prestise, ketersohoran, konsekrasi atau kehormatan, dan dibangun di atas dialektika pengetahuan dan pengenalan (Bourdieu dalam Krisdinanto, 2014:203).

Hal tersebut senada dengan yang diungkapkan Baswedan (dalam Fuad,dkk. 2013:7) dalam penelitiannya yaitu kelompok Islam substantif diwakili oleh sebagian aktivis Islam yang aktif di berbagai organisasi masyarakat sipil dan partai nasionalis. Di sini tampak bahwa ada pergeseran Muslim Indonesia terkait dengan aspirasi politiknya. Mereka berpikir bahwa aspirasi politik Islam bisa disalurkan lewat partai lain yang bervisi inklusif dan kebangsaan. Fuad Amin menggunakan gelar Kiai dimanfaatkan sebagai tunggangan untuk maju di dunia politik Bangkalan. 


\section{Modal Simbolik Fuad Amin}

Modal simbolik merujuk pada pembawaan yang didasarkan prestasi ataupun kemampuan individu atau kelompok dan dibangun dari dialektika pengetahuan (connaissance) dan pengenalan. Modal simbolik berhubungan dengan kekuasaan simbolik (Bourdieu dalam Krisdinanto, 2014 :203). Keempat narasumber sepakat bahwa gelar kiai yang melekat pada diri Fuad Amin menjadikan Fuad Amin disegani serta dipercaya. Itu merupakan modal simbolik yang dimiliki Fuad Amin dimana simbol kiai adalah figur pengayom dan penyelamat bagi masyarakat. Kiai sebagai penyelamat dari sudut pandang narasumber yaitu figur yang mengajarkan ilmu dari ketidaktahuan menjadi mengetahui, terutama dalam konteks agama Islam. Fuad Amin yang merupakan keturunan dari Syaichona Cholil menarik untuk disoroti kembali pada detail modal ini.

Gelar tersebut memunculkan kuasa simbolik yang dimiliki Fuad Amin dalam menggerakan massa untuk kepentingannya, terutama dalam konteks politik. Dengan itu, seperti yang diungkap Bourdieu (dalam Krisdinanto, 2014:202) Fuad Amin bisa menciptakan realitas atau sesuatu hal yang diakui masyarakat Madura terutama Bangkalan, tentang cara pandang memahami dunia. Hal itu ternaturalisasi di wilayah Bangkalan yang kembali lagi berdampak pada keuntungan Fuad Amin secara politis. Salah satu narasumber yaitu Mukarom menjelaskan bahwa dukungan dirinya pada Fuad Amin tidak terlepas dari pemahamannya pribadi terhadap agama yang dipelajari. Dia menekankan untuk memilih pemimpin yang agamanya (Islam) baik dan mempunyai pengetahuan agama lebih tinggi dari lainnya. Dia beranggapan dengan kriteria seperti itu, sudahlah pasti seseorang itu adalah pemimpin yang terbaik. Dia menuturkan walaupun ada yang berpendidikan secara akademis tinggi, ataupun menawarkan sesuatu kemajuan kearah yang lebih modern tapi tetap kecil kemungkinannya untuk dirinya memilih ataupun simpati pada individu/kelompok tersebut. Hal itu karena baginya yang terkait dengan kepercayaannya, wajib hukumnya memilih orang yang tinggi ilmu agamanya. Bila semua calon bupati memiliki ilmu agama yang tinggi, maka dia memutuskan untuk memilih yang paling tinggi ilmu agamanya diantara lainnya. Hal tersebut kembali lagi pada gelar kiai dan keturunan ulama besar yang melekat pada Fuad Amin.

Samsul, Narasumber yang bekerja di kantor pemerintahan mengaku dirinya tidak berani mengkritik gagasan Fuad Amin dan merasa aman jika tetap pada kelompok yang mendukung Fuad Amin sebagai bupati Bangkalan ataupun orang yang memangku kekuasaan dalam pemerintahan. Hal tersebut menunjukan adanya kekuasaan yang secara langsung maupun tidak langsung berdampak pada pemikiran narasumber. Kecemasan bila tidak mendukung ataupun mengkritik hal yang berkaitan dengan Fuad Amin menunjukan adanya intimidasi yang merupakan kekerasan simbolik yang dirasakan narasumber.

Dua narasumber lainnya berpendapat bahwa Fuad Amin mempunyai wibawa yang disinyalir bisa memimpin bangkalan. Menurut mereka masyarakat di Bangkalan bisa patuh dan tidak akan ada keributan antar masyarakat Bangkalan. Modal gelar kiai setra citra sosok keturunan ulama besar masih berdampak pada kedua narasumber ini. Mereka beranggapan tidak ada yang berani dengan kiai, termasuk Fuad Amin. Terlebih Fuad Amin adalah keturunan ulama besar. Bila itu dilanggar, maka hilang juga keberkahan suatu daerah tersebut. Merujuk pada Bourdieu (dalam Krisdinanto, 2014:202) bahwa mekanisme kuasa simbolik terbentuk melalui doksa, yang artinya adalah kepercayaan secara mendasar yang tidak perlu dipertanyakan, seperti suatu dogma. Jadi perilaku yang dia lakukan karena dorongan politik Fuad Amin tidak dipertanyakan lagi tentang kekurangan dan kelebihannya.

Bila dilihat dari keempat unsur modal tersebut, modal satu dengan yang lainnya saling berhubungan dan saling mendukung. Bahkan, modal satu dengan yang lainnya bisa dipertukarkan. Seperti yang dijelaskan Bourdieu (dalam Harker, 2009:17) tentang pertukaran modal tersebut, selama masa kampanye adalah masa dimana Fuad Amin membutuhkan banyak biaya, namun dengan biaya tersebut terbentuklah sosialisasi dan pembentukan citra sehingga menjadi modal simbolik, budaya, dan sosial. Begitu pula dengan modal simbolik berupa gelar kiai dan modal sosial yang merupakan keturunan ulama besar, modal simbolik Fuad Amin bertambah kuat apalagi setelah menduduki kekuasaan menjadi bupati Bangkalan.

\section{KESIMPULAN}

Fuad Amin memiliki keempat modal yang saling berhubungan dan saling menguntungkan. Modal tersebut juga bisa dipertukarkan dan saling menguatkan. Modal simbolik yang dimiliki Fuad Amin dengan gelarnya kiai merupakan entry point kepercayaan masyarakat Bangkalan untuk setia mempercayakan Bangkalan kepada Fuad Amin. Ditambah lagi secara stratifikasi sosial Fuad Amin merupakan keturunan ulama besar dari Bangkalan yang merupakan salah satu pendiri di salah satu organisasi Islam Terbesar di Indonesia. Dengan modal tersebut Fuad Amin mempunyai kuasa, baik secara langsung maupun simbolik. Dengan kekuasaan tersebut Fuad Amin bisa memanfaatkannya untuk kepentingan politiknya. Terjadi naturalisasi sudut pandang yang tidak terlepas dari faktor budaya, ekonomi, maupun sosial masyarakat Bangkalan, bahwa dominasi kiai terhadap pemerintahan harus tetap dilestarikan. Pada akhirnya terjadilah semacam dogma yang melekat pada masyarakat Bangkalan bahwa keturunan ulama besar yang juga menyandang gelar kiai adalah sosok yang ideal menjadi pemimpin terlepas dari pendidikan akademiknya serta prestasi yang dia miliki pada jabatannya sebelumnya.

Penelitian ini menemukan kekerasan simbolik sebagai dampak dari mekanisme kapital Fuad Amin. Modal saling dipertukarkan untuk memperkuat modal simbolik, yaitu status menjadi bupati. Bupati artinya orang nomor satu di wilayah 
tersebut. Kepercayaan sebagian masyarakat Bangkalan pada simbol kiai membuat suatu nilai dominan yang seakan harus dipatuhi. Modal yang membangun kekuasaan simbolik tersebut memunculkan kekerasan simbolik berupa intimidasi bagi orang yang tidak mendukung Fuad Amin. Dengan begitu keempat modal tersebut menjadi instrumen Fuad Amin dalam meraih kekuasaan.

\section{DAFTAR PUSTAKA}

Adib, Mohammad, “Agen dan Struktur dalam Pandangan Pierre Bourdieu”. Jurnal Biokultur. Surabaya, Vol 1(2), 2012, pp 91-110

Abdussalam, Moh. Ishaq, "Reproduksi Kekuasaan Kiai dan Blater di Kabupaten Bangkalan”. Jurnal Dimensi. Bangkalan, Vol 7(1), 2015

Chalik, Abdul. "Elite Lokal Berbasis Pesantren Dalam Kontestasi Pemilihan Kepala Daerah Di Jawa Timur". Jurnal Karsa. Pamekasan, Vol 23(2), 2015, Pp 363-381

Dwizatmiko. "Kuasa Simbolik Menurut Pierre Bourdieu: Telaah Filosofis”. Universitas Indonesia : Jakarta, 2010

Fauzi, Ahmad, "Habitualisasi Nilai-Nilai Kepemimpinan Transformatif Perspektif Kiai Hasan Mutawakkil 'Alallah”. Jurnal Manageria. Yogyakarta, Vol 3(2), 2018, pp 1-19

Harker, Richard, Mahar, Cheelen, dan Wilkes, Chris. (2009). (Habitus X Modal) + Ranah = Praktik Pengantar Paling Komprehensif kepada Pemikiran Pierre Bourdieu. Yogyakarta: Jalasutra

Hermansyah, H, “Kearifan Lokal Manusia Perahu (Suku Bajo) di Kepulauan Sapeken Kabupaten Sumenep”. UIN Sunan Ampel : Surabaya, 2015

Ihsan, A. Bakir, "Rekonstruksi dan Revitalisasi Koalisi dalam Sistem Quasi Presidensial”. Jurnal Penelitian Politik. Jakarta. Vol : 8(1), 201, pp 31-43

Ja'far, Suhermanto, "Runtuhnya watak polimorfik Kiai dalam kultur masyarakat Madura”. Jurnal Al.Adalah. Bandar Lampung. Vol 17(2), 2014, pp 177-196

Okezone.com. (2017). Alamak! Kemiskinan di Madura Tertinggi Se-Jawa Timur, Ini Buktinya. Retrieved December 18, 2019, from okezone.com website https:/economy.okezone.com/read/2017/09/13/320/1774854/alamakkemiskinan-di-madura-tertinggi-se-jawa-timur-ini-buktinya

Krisdinanto, Nanang, "Pierre Bourdieu, Sang Juru Damai”. Jurnal Kanal. Sidoarjo, Vol 2(2), 2014, 191- 206

Marhaeni, Dian dan Mulyadi, Urip, "Praktek Politik Kapitalis, Kekuasaan dan Kelas Pada Tayangan Iklan Anak di Media Online”. Channel Jurnal Komunikasi. Yogyakarta. Vol 7(1), 2019, 67-72

Mu'azaroh, Siti, “Cultural Capital dan Kharisma Kiai dalam Dinamika Politik : Studi Ketokohan K.H. Maimun Zubair”. Jurnal In Right. Yogyakarta. Vol 6(2), 2017, pp 195-212

Neuman, W. Lawrence, “Metode penelitian sosial: Pendekatan Kualitatif dan Kuantitatif : Edisi Ketujuh”. Jakarta : PT Indeks. 2013

Pramudhita, Okky., Anang, Sujoko dan Antoni, "Industri Radio Indonesia dalam Hegemoni Kapitalisme : Kajian Kritis Studi Media". Channel Jurnal Komunikasi. Yogyakarta. Vol 6(2), 2018, 131-138

Pramudyanto, Alexander Beny.(2013). Media Baru dan Peluang Counter Hegemony Atas Dominasi Logika Industri Musik: Studi Kasus Perkembangan Netlabel di Indonesia. Jurnal Ilmu Komunikasi.10(1), 63-82

Raditya, Iswara N. (2019). Sejarah Hidup Fuad Amin : Wafatnya Sang Penguasa Bangkalan. Retrieved December 17, 2019, from Tirto.id website https://irto.id/sejarah-hidup-fuad-amin-wafatnya-sang-penguasa-bangkalan-maduraeifT

Ruji, Muhammad, "Pengaruh Trah Kiai Dalam Kontestasi Politik Pemilukada Di Kabupaten Bangkalan Periode 20032013 M”. UIN Sunan Ampel. Surabaya. 2016

Sahuri, Abdullah. (2019). Bangkalan dan Arah Pembangunan. Retrieved December 15, 2019, from kabarmadura.id website https://kabarmadura.id/bangkalan-dan-arah-pembangunan/

Saputra, Andi. (2018). Bupati Fuad Amin, Koruptor Rp.414 Miliar yang Bikin Geger LP. Retrieved December 16, 2019, from detik.com website https://news.detik.com/berita/d-4127094/bupati-fuad-amin-koruptor-rp-414-miliar-yangbikin-geger-lp 
Satriawan, M. Iwan, "Pengawasan Pemilukada oleh Rakyat : Upaya Mencegah Pelanggaran Pemilukada”. Jurnal Bawaslu. Vol 2(1), 2016, pp 89-107

Supriyadi, "Modus-Modus Pelanggaran Dalam Pemilukada : Pembentukan Kampung Pasangan Calon Pada Pilkada". Jurnal Bawaslu. Vol 2(2), 2016, pp 74-87

Susanto, Edi, “ Kepemimpinan Kharismatik Kiai Dalam Perspektif Masyarakat Madura”. Jurnal Karsa. Pamekasan. Vol 11(1), 2007, pp 30-40

Warsito, "Pemilihan kepala daerah”. Jurnal Dialogue. Semarang, Vol 2(3), 2005, pp 914-926

Wijaya, A. Latief, “Carok Konflik Kekerasan dan Harga Diri Orang Madura”. Yogyakarta: Lkis. 2006

Yahya, H. Imam, “Demokrasi Pesantren”. Jurnal Taqaddum. Semarang. Vol 6(2), 2014, pp 187-205 